\title{
Antipyretic effect of methanolic extracts of Limnophila repens and Argyreia cymosa whole plant on albino rats
}

\begin{abstract}
Objective: The aim of the study was to evaluate the antipyretic activity of methanolic whole plant extracts of Limnophila repens (L. repens) and Argyreia cymosa (A. cymosa) using Brewer's yeast-induced pyrexia model.

Materials and methods: It was a randomized controlled experimental study. A total of 60 rats were taken, dividing them into six groups, each containing ten rats. Methanolic extract of L. repens (MELR) and A. cymosa (MEAC) was administered at 200, and $400 \mathrm{mg} / \mathrm{kg}$ doses orally to the respective four groups. The control group was fed with normal saline at $2 \mathrm{ml} / \mathrm{kg}$. A $20 \%$ suspension of Brewer's yeast in normal saline was injected subcutaneously at a dose of $10 \mathrm{ml} / \mathrm{kg}$ body weight under the nape of the throat of rodents in all groups. Pyrexia produced following ten $\mathrm{h}$ of Brewer's yeast injection, and the temperature was recorded. Drugs received soon after the development of pyrexia and temperatures were recorded. Paracetamol at $150 \mathrm{ml} / \mathrm{kg}$ orally was taken as the conventional medication.

Results: The MELR and MEAC were showed significant $(\mathrm{P}<0.05)$ antipyretic activity at $400 \mathrm{mg} / \mathrm{kg}$. Paracetamol showed substantial antipyretic activity from $30 \mathrm{~min}$ of drug administration to $180 \mathrm{~min}$. At $400 \mathrm{mg} / \mathrm{kg}$ dosage the extracts (MELR and MEAC) revealed a considerable decrease in yeast evoked raised temperature when compared with that of standard drug paracetamol where by the extract dose $200 \mathrm{mg} / \mathrm{kg}$ had been less effective as compared to the higher dose $(\mathrm{p}<0.05)$.
\end{abstract}

Conclusion: This research confirmed that MELR and MEAC at a dose of 200 and 400mg/ $\mathrm{kg}$ own considerable antipyretic outcome against the yeast-induced raised temperature. However, the active chemical constituents responsible for the antipyretic action need to be investigated further.

Keywords: antipyretic, paracetamol, phytochemical screening, limnophila repens, argyreia pilosa
Volume 5 Issue 6 - 2018

\author{
Venkateswarlu G,' Ganapathy S² \\ 'Department of Pharmacognosy and Phytochemistry,A.M. \\ Reddy Memorial College of Pharmacy, India \\ ${ }^{2}$ Department of Pharmacognosy and Phytochemistry, Gitam \\ University, India
}

\begin{abstract}
Correspondence: Department of Pharmacognosy and Phytochemistry,A.M. Reddy Memorial College of Pharmacy, India,Email gyr9885@gmail.com
\end{abstract}

Received: September 25, 2018 | Published: November 20, 2018

\section{Introduction}

For years, natural treatments and particularly therapeutic vegetation had been the primary or even the sole alternative of our ancestors for their remedy. However, despite the development of the pharmaceutical industry, medicinal plants and treatments that could be drawn were never abandoned entirely, and people continue to resort to traditional medicine. ${ }^{1}$ Natural products are believed to be an essential source of new chemical substances with the potential therapeutic application. Several plant species were traditionally used as analgesics. In general, the herbal plant usage in the treatment of disease and pain relief is one of the important strategies in medicine. ${ }^{2}$

The genus Limnophila is frequently used in the traditional medicine against cardiovascular diseases, stomach disorders, elephantiasis, diarrhoea, dyspepsia, fever, dysentery, indigestion, Dysmenorrhoea and abdominal pain..$^{3-5}$

Phytochemical analysis of genus Limnophila revealed the presence of the number of phytoconstituents such as flavonoids, tannins, alkaloids, terpenoids, steroids, and glycosides. ${ }^{6}$ This diversity in compounds could justify the traditional use of L. repens.

The genus Limnophila is relatively abundant and widely used in folk medicine as an antioxidant, ${ }^{7,8}$ antimicrobial ${ }^{9}$ anticancer, ${ }^{10}$ antimycobacterial, ${ }^{11}$ as on to date no biological studies have been conducted on this plant.

Argyreia cymosa is a decorative, as well as a therapeutic herb. Every part of the herb will be traditionally used being a folklore medication for the management of numerous illnesses by the Indian traditional healer. Its root is employed to remedy numerous diseases like STD viz., gonorrhoea and syphilis, blood diseases. Conventionally, the paste of the leaves is placed on the throat area for coughing, quinsy and then used outwardly in case of itch, dermatitis and other skin troubles, ant diabetic, antichloristic, rheumatism and minimize burning sensation. ${ }^{12}$ A vast range of photochemical constituents has been separated from the genus Argyreia, i.e., glycosides, alkaloids, amino acids, proteins, flavonoids, triterpene and steroids. ${ }^{13}$ The plant has been reported a few biological activities including Antibacterial ${ }^{14}$ and antioxidant. ${ }^{14}$ Even though the drug has many uses, it's pharmacological, and photochemistry is very poorly explored.

Traditionally, both plants were utilized for antipyretic activity, but till date, no scientific evidence has been reported. Therefore, the current study has been carried out with the methanolic extract of $L$. repens (MELR) and A. cymosa (MEAC) to investigate its antipyretic activity against baker's yeast-induced fever in rabbits using paracetamol as a reference standard. 


\section{Materials and methods}

\section{Plant material}

The plants $L$. repens and $A$. cymosa were collected from Tirupathi, Chittoor district of Andhra Pradesh was authenticated at Botany Division, Sri Venkateswara University. The voucher specimen (No. 1568 and 1043) were deposited at herbarium and raw drug depository respectively. The plant components had been dried out under shade for Two weeks, coarsely powdered and then kept in air restricted canisters guarded against humidity and sunlight for further study.

\section{Preparation of extract}

About $250 \mathrm{~g}$ of the powdered crude drug of $L$. repens and $A$. cymosa were extracted by cold maceration with $1000 \mathrm{~mL}$ of methanol for $18 \mathrm{~h}$ after pre-treatment with petroleum ether. Both extracts obtained had been concentrated to dryness in the vacuum at $40^{\circ} \mathrm{C}$ and kept at $4^{\circ} \mathrm{C}$ inside the refrigerator till further used. The extracts had been subjected to photochemical and pharmacological evaluation.

\section{Photochemical screening}

The various extract of $L$. repens and $A$. cymosa were subjected to qualitative chemical analysis by using standard procedures. ${ }^{11-14}$

\section{Animal used}

Adults Wistar albino rats of either sex weighing 180-200g each were used. The animals had been maintained in the regular metallic cages in sets of 6 per cage, with free access to standard diet and drinking water ad libitum in the animal house and kept at room temperature under suitable dietary and environmental circumstances throughout the experiment. The Institutional Animal Ethics Committee examined the complete animal protocols ahead of performing the trials.

\section{Drugs, reagents, and apparatus used}

Paracetamol, Baker yeast, Distilled water and Digital Thermometer.

\section{Acute toxicity study}

To evaluate the degree of toxicity of L. repens methanolic extract, the acute toxicity study was worked based upon OECD (Organization for Economic Cooperation and Development) 423 recommendations to the dose of $2000 \mathrm{mg} / \mathrm{Kg}$. The experimental animals had been noticed for $1 \mathrm{~h}$ constantly after which hourly for $4 \mathrm{~h}$ and lastly every $24 \mathrm{~h}$ up to 14 days for any physical symptoms of the level of toxicity, including writhing, gasping, palpitations and lowered respiratory rate or mortality. No animals died. Therefore the $\mathrm{LD}_{50}$ is greater than 2000 $\mathrm{mg} / \mathrm{kg}$. Pre-screening investigation with 200 and $400 \mathrm{mg}$ per body weight was done. ${ }^{15}$

\section{Anti-pyretic activity}

The animals were randomly divided into six groups, each group consisting of 10 rats; a total of 60 rats were used in the study by randomized sampling technique: group I (control, normal saline given orally at $2 \mathrm{ml} / \mathrm{kg}$ body weight); group II (standard, paracetamol 150mg/ $\mathrm{kg}$ ); group s III and IV [methanolic extract of L. repens (MELR)], V and VI [methanolic extract of A. cymosa (MEAC) 200, and 400mg/ $\mathrm{kg}$, respectively]. This is certainly a traditional way of antipyresis screening. Wistar strain of albino rats of either sex weighing 100$200 \mathrm{~g}$ was used for the study. The animals had fasted for $18 \mathrm{~h}$ before the beginning of the test, yet water was supplied ad libitum. The initial rectal temperature was recorded by using a rectal thermometer to a depth of $1.5 \mathrm{~cm}$ in the rectum of rodent. Animals with a body temperature between 36 and $38^{\circ} \mathrm{C}$ had been as part of the research. A $20 \%$ Brewer's yeast in $0.9 \% \mathrm{w} / \mathrm{v}$ saline was injected subcutaneously under the nape of the throat at a dose of $10 \mathrm{ml} / \mathrm{kg}$ thereafter. The injection site was rubbed so that the spread of suspension under the skin. Room temperature was maintained at $22-24^{\circ} \mathrm{C}$. Following the yeast injection, food was instantly withdrawn. After $10 \mathrm{~h}$ postchallenge, the rise in rectal temperature was recorded. Animals which demonstrated an increase in body's temperature to $39^{\circ} \mathrm{C}$ had been included in the research, enabling the minimum of six rats in every group, the total of 36 rats. The animals received the standard (paracetamol $150 \mathrm{mg} / \mathrm{kg}$ ) or the test compound (MELR and MEAC 200 and $400 \mathrm{mg} / \mathrm{kg}$ ) by oral administration, and the rectal temperature was recorded at $0,30,60,90,120$ and $180 \mathrm{~min}$ after dosing. The maximum reduction in average rectal temperature in comparison with the control hyperpyrexia group was calculated and compared. ${ }^{16}$

\section{Statistical analysis}

Statistical analysis was carried out using Graph Pad Prism 5.0 (Graph Pad Software, San Diego, CA). All results were expressed as mean \pm SD. The data were analyzed by one-way ANOVA followed by Tukey multiple comparison tests.

\section{Results}

\section{Acute toxicity studies}

The MELR and MEAC, when orally administered in the dose of $2000 \mathrm{mg} / \mathrm{kg}$ body wt. did not produce any significant changes in the autonomic or behavioural responses, including death during the observation period. Photochemical Screening

The photochemical screening for methanolic extracts of $L$. repens and A. cymosa were carried out, and results were displayed in Table 1.

Table I Phytochemical analysis of the methanolic extract of Argyreia cymosa (MEAC) and methanolic extract of Limnophila repens (MELR)

\begin{tabular}{llll}
\hline Phytoconstituents & Method & MEAC & MELR \\
\hline \multirow{2}{*}{ Flavonoids } & Shinoda Test & + & + \\
& Zn. Hydrochloride test & + & + \\
Volatile oil & Lead acetate Test & + & + \\
& Stain test & - & - \\
Alkaloids & Wagner Test & + & + \\
& Hager's Test & + & + \\
Tannins \& & Fecl ${ }_{3}$ Test & + & + \\
Phenols & Potassium dichromate test & + & + \\
Saponins & Foaming Test & - & - \\
Steroids & Salkowski test & + & + \\
Carbohydrates & Molish test & - & + \\
Acid compounds & Litmus test & + & - \\
Glycoside & Keller-Killani Test & + & + \\
Amino acids & Ninhydrin test & + & + \\
Proteins & Biuret & + & + \\
\hline
\end{tabular}

“+”- Present and “-"-Absent 


\section{Antipyretic activity}

Subcutaneous injection of the pyrogenic dose of yeast produced elevated changes in rectal temperature, which is shown in Table 2 . The MELR and MEAC showed a significant $(\mathrm{P}<0.05)$ decrease in rectal temperature at dose $400 \mathrm{mg} / \mathrm{kg}$ when compared with the standard. Extract at doses of 200 , and $400 \mathrm{mg} / \mathrm{kg}$ showed a progressive decline in mean temperature pattern with the increase in the dose. Paracetamol showed significant $(\mathrm{P}<0.001)$ decrease in rectal temperature. The onset of action of paracetamol was $30 \mathrm{~min}$. The line graph (Fig. 1) shows that paracetamol registered a phenomenal decrease in mean temperature from $38.7 \pm 0.12$ to $37.01 \pm 0.42$. Illustrates that the most significant $(\mathrm{P}<0.05)$ decrease in round-the-clock mean temperature in this study was shown by paracetamol followed by MELR and MEAC at $400 \mathrm{mg} / \mathrm{kg}$ and $200 \mathrm{mg} / \mathrm{kg}$. Statistical analysis was performed using one-way analysis of variance followed by Tukey's test. The consequences of extract at a dose of $400 \mathrm{mg} / \mathrm{kg}$ were nearly much like that of standard drug paracetamol. The results were recorded as mean \pm SD. Out of all the groups apart from negative control; the temperature became normal through $3 \mathrm{~h}$ of study (Figure 1, Table 2).

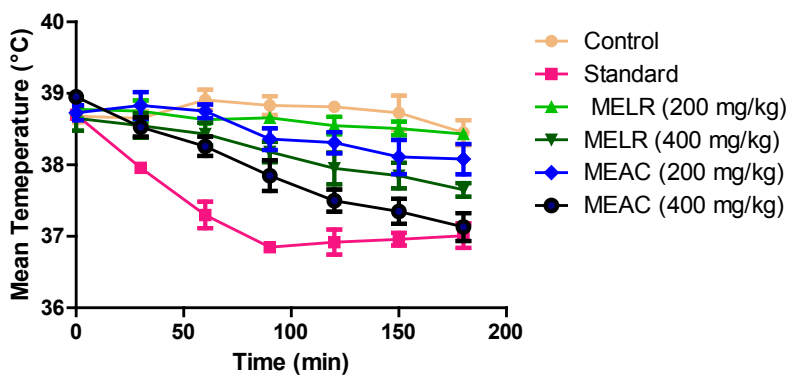

Figure I Line graph showing the effect of paracetamol and MELR and MEAC at 200 and $400 \mathrm{mg} / \mathrm{kg}$ on yeast-induced pyrexia in rats.

Table 2 Effect of MELR and MEAC on yeast extracts induced pyrexia in Rats. All values expressed as mean \pm SEM; $n=6$ rats in each group, by one-way ANOVA followed by Tukey's multiple comparison Test. \#, $\mathrm{p}<0.00 \mathrm{I}$ Vs paracetamol (I $50 \mathrm{mg} / \mathrm{Kg}) ; \mathrm{a}, \mathrm{p}<0.0 \mathrm{I}$ Vs paracetamol (I50mg/Kg) and b, $\mathrm{p}<0.05 \mathrm{Vs}$ Control.

\begin{tabular}{|c|c|c|c|c|c|c|c|c|}
\hline \multirow{2}{*}{ Groups } & \multirow{2}{*}{ BBT } & \multicolumn{7}{|c|}{ Rectal Temperature $\left({ }^{\circ} \mathrm{C}\right)$ after $10 \mathrm{~h}$ of yeast injection } \\
\hline & & Omin & $30 \mathrm{~min}$ & $60 \mathrm{~min}$ & $90 \mathrm{~min}$ & $120 \mathrm{~min}$ & $150 \mathrm{~min}$ & $180 \mathrm{~min}$ \\
\hline Control & $37.12 \pm 0.23$ & $38.68 \pm 0.21$ & $38.65 \pm 0.25$ & $38.91 \pm 0.35$ & $38.83 \pm 0.32$ & $38.81 \pm 0.18$ & $38.73 \pm 0.58$ & $38.45 \pm 0.43$ \\
\hline $\begin{array}{l}\text { Standard (Paracetamol } \\
150 \mathrm{mg} / \mathrm{kg})\end{array}$ & $37.16 \pm 0.21$ & $38.7 \pm 0.12^{\#}$ & $37.96 \pm 0.18^{\#}$ & $37.3 \pm 0.45^{\#}$ & $36.85 \pm 0.15^{\#}$ & $36.92 \pm 0.43^{\#}$ & $36.96 \pm 0.22^{\#}$ & $37.01 \pm 0.42^{\#}$ \\
\hline MELR $(200 \mathrm{mg} / \mathrm{kg})$ & $37.25 \pm 0.19$ & $38.78 \pm 0.33^{a}$ & $38.75 \pm 0.37^{a}$ & $38.63 \pm 0.13^{\mathrm{a}}$ & $38.66 \pm 0.12^{\mathrm{a}}$ & $38.55 \pm 0.3^{\mathrm{a}}$ & $38.5 I \pm 0.23^{a}$ & $38.43 \pm 0.16^{\mathrm{a}}$ \\
\hline MELR $(400 \mathrm{mg} / \mathrm{kg})$ & $37.18 \pm 0.22$ & $38.65 \pm 0.42^{\mathrm{b}}$ & $38.55 \pm 0.23^{b}$ & $38.43 \pm 0.39^{b}$ & $38.18 \pm 0.35^{b}$ & $37.95 \pm 0.54^{b}$ & $37.85 \pm 0.44^{b}$ & $37.65 \pm 0.23^{b}$ \\
\hline MEAC $(200 \mathrm{mg} / \mathrm{kg})$ & $37.08 \pm 0.16$ & $38.73 \pm 0.26$ & $38.83 \pm 0.46$ & $38.75 \pm 0.23$ & $38.36 \pm 0.37$ & $38.3 I \pm 0.36$ & $38.11 \pm 0.58$ & $38.08 \pm 0.52$ \\
\hline MEAC $(400 \mathrm{mg} / \mathrm{kg})$ & $37.16 \pm 0.13$ & $38.95 \pm 0.18^{b}$ & $38.53 \pm 0.33^{b}$ & $38.26 \pm 0.33^{b}$ & $37.85 \pm 0.53^{b}$ & $37.5 \pm 0.38^{b}$ & $37.35 \pm 0.43^{b}$ & $37.13 \pm 0.48^{b}$ \\
\hline
\end{tabular}

\section{Discussion}

Fever is the main defensive reaction referred to as the "acute phase reaction", which happen throughout the inflamed processes of various sources. Brewer's yeast (lipopolysaccharide that is the cell wall element of Gram-negative bacteria) is an exogenous pyrogen which binds to the immunological protein referred to as lipopolysaccharide binding protein. This kind of binding leads to the synthesis as well as the release of numerous endogenous cytokine factors, for example, interleukin (IL)-1, IL-6, and TNFa, that trigger the arachidonic acid pathway, and also eventually result in the synthesis and release of prostaglandin $\mathrm{E}_{2}\left(\mathrm{PGE}_{2}\right)$. Yeast-induced pyrexia is termed as pathogenic fever. ${ }^{17}$

Based on the traditional perspective, fever is evoked through inflamed mediators (I L-1, IL-2, TNF $\alpha$, others) unveiled through the peripheral mononuclear macrophages and other immune cells. ${ }^{18}$ These fever-promoting cytokines tend to be moved through the bloodstream to the brain by particular carriers. ${ }^{19}$ Cytokines are carried through the blood stream and also enter the brain through the circumventricular organs..$^{20}$ On the other hand, the cytokines might interact with their receptors on brain endothelial cells or perivascular tissue. ${ }^{21}$ This presumed mechanism of fever induction is called the humoral hypothesis of fever induction. These pro-inflammatory mediators address the preoptic/anterior hypothalamus activating the release of $\mathrm{PGE}_{2}$ made out of cyclooxygenase (COX-2), and therefore increasing the body temperature. ${ }^{22}$

In this study, orally administered paracetamol at $150 \mathrm{mg} / \mathrm{kg}$ significantly attenuated baker's yeast-induced fever in rats. Our study results are matching to other studies that have also shown the reduction of temperature in rats by paracetamol at the same dose. Antipyretics and non-steroidal anti-inflammatory drugs (NSAIDS) reduce temperature by inflammation reduction in the peripheral and CNS thermoregulatory sites.

In the current study, L. repens and A. cymosa methanolic extracts reduced baker's yeast-induced fever in rats significantly. The preliminary phytochemical study of both plants revealed the presence of flavonoids, alkaloids, tannins, phenols, steroids, glycosides, amino acids, and proteins majorly. The presence of these bioactive compounds may be responsible for the antipyretic activity of these extracts as sterols like $\beta$-Sitosterol ${ }^{23}$ have the antipyretic effect. Alkaloids such as bolidine can reduce the raised temperature by suppressing the prostaglandin $\mathrm{E}_{2}$ synthesis. ${ }^{24}$ In the same manner, flavonoids such as baicalin have the antipyretic outcome by curbing $\mathrm{TNF} \alpha .{ }^{25}$ It could be assumed that MELR and MEAC have antipyretic effect by reducing the concentration of $\mathrm{PGE}_{2}$ in the hypothalamus or by interrupting the steps that connect the peripheral inflammation with the central production of $\mathrm{PGE}_{2}$ or both. ${ }^{26}$

\section{Conclusion}

It is concluded that MELR and MEAC have significant antipyretic activity. The traditional use of L. repens and A. cymosa in fever is supported by this study, and it would encourage its use in fever with the greater degree of assurance of its efficacy. It is recommended to determine the active chemical constituents accountable for the antipyretic activity. 


\section{Acknowledgements}

None.

\section{Conflict of interest}

The author declares there is no conflict of interest.

\section{References}

1. Metrouh Amir H, Amir N. Evaluation in vivo of anti-inflammatory and analgesic properties of Matricaria pubescens alkaloids. South African Journal of Botany. 2018;116:168-174.

2. Husseini Y, Sahraei H, Meftahi GH, et al. Analgesic and anti-inflammatory activities of hydro-alcoholic extract of Lavandula officinalis in mice: possible involvement of the cyclooxygenase type 1 and 2 enzymes. Revista Brasileira de Farmacognosia. 2016;26(1):102-108.

3. Les DH. Aquatic dicotyledons of North America: ecology, life history, and systematic. CRC Press; 2017.

4. Hsu H, Chen Y, Sheu S. Oriental materia medica: a concise guide. Keats Publishing Inc; 1996.

5. Pullaiah T. Encyclopaedia of world medicinal plants. Daya books; 2006

6. Brahmachari G. Limnophila (Scrophulariaceae): Chemical and Pharmaceutical Aspects-An Update. The Open Natural Products Journal. 2014;7(1):1-14.

7. Do QD, Angkawijaya AE, Tran Nguyen PL, et al. Effect of extraction solvent on total phenol content, total flavonoid content, and antioxidant activity of Limnophila aromatica. J Food Drug Anal. 2014;22(3):296302 .

8. Kukongviriyapan U, Luangaram S, Leekhaosoong K, et al. Antioxidant and vascular protective activities of Cratoxylum formosum, Syzygium gratum and Limnophila aromatica. Biol Pharm Bull. 2007;30(4):661666.

9. Rao JV, Aithal KS, Srinivasan K. Antimicrobial activity of the essential oil of Limnophila gratissima. Fitoterapia. 1989;60(4):376-377.

10. Nanasombat S, Teckchuen N. Antimicrobial, antioxidant and anticancer activities of Thai local vegetables. Journal of Medicinal Plants Research. 2009;3(5):443-449.

11. Suksamrarn A, Poomsing P, Aroonrerk N, et al. Antimycobacterial and antioxidant flavones from Limnophila geoffrayi. Arch Pharm Res. 2003;26(10):816-820.
12. Marles RJ, Farnsworth NR. Antidiabetic plants and their active constituents. Phytomedicine. 1995;2(2):137-189.

13. Galani VJ, Patel BG. Psychotropic activity of Argyreia speciosa roots in experimental animals. Ayu. 2011;32(3):380-384.

14. Packialakshmi N, Beevi HF. Antibacterial Screening on Leaves of Argyreia Cymosa Roxb. Against Pathogenic Bacteria Isolated from Infected Pateints Samples Wound, Sputum and Stool. Int J Appl Sci Biotechnol. 2014;2(3):279-282.

15. Kiran PM, Raju AV, Rao BG. Investigation of hepatoprotective activity of Cyathea gigantea (Wall. ex. Hook.) leaves against paracetamol-induced hepatotoxicity in rats. Asian Pac J Trop Biomed. 2012;2(5):352-356.

16. Vogel HG. Drug discovery and evaluation: pharmacological assays. Springer Science \& Business Media; 2002.

17. Bhattacharya A, Behera R, Agrawal D, et al. Antipyretic effect of ethanolic extract of Moringa oleifera leaves on albino rats. Tanta Medical Journal. 2014;42(2):74-78.

18. Zeisberger E. From humoral fever to neuroimmunological control of fever. J Therm Biol. 1999;24(5):287-326.

19. Banks WA, Plotkin SR, Kastin AJ. Permeability of the blood-brain barrier to soluble cytokine receptors. Neuroimmunomodulation. 1995;2(3):161165 .

20. Roth J, Harré EM, Rummel C, et al. Signaling the brain in systemic inflammation: role of sensory circumventricular organs. Front Biosci. 2004;9(7):290-300.

21. Schiltz JC, Sawchenko PE. Signaling the brain in systemic inflammation: the role of perivascular cells. Front Biosci. 2003;8:s1321-s1329.

22. Saper CB, Breder CD. The neurologic basis of fever. $N$ Engl J Med. 1994;330(26):1880-1886.

23. Gupta M, Nath R, Srivastava N, et al. Anti-inflammatory and antipyretic activities of $\beta$-sitosterol. Planta Med. 1980;39(2):157-163.

24. Backhouse N, Delporte C, Givernau M, et al. Anti-inflammatory and antipyretic effects of boldine. Agents Actions. 1994;42(3-4):114-117.

25. Chang CP, Huang WT, Cheng BC, et al. The flavonoid baicalin protects against cerebrovascular dysfunction and brain inflammation in experimental heatstroke. Neuropharmacology. 2007;52(3):1024-1033.

26. Li S, Dou W, Tang Y, et al. Acetaminophen: antipyretic or hypothermic in mice? In either case, PGHS-1b (COX-3) is irrelevant. Prostaglandins Other Lipid Mediat. 2008;85(3-4):89-99. 